\title{
Born to be green: new insights into the economics and management of green entrepreneurship
}

\author{
Pelin Demirel • Qian Cher Li • Francesco Rentocchini • \\ J. Pawan Tamvada
}

Accepted: 30 June 2017 / Published online: 4 October 2017

C) The Author(s) 2017. This article is an open access publication
Keywords Green entrepreneurship · Environmental sector $\cdot$ Green economy $\cdot$ Green start-ups

JEL classifications $\mathrm{L} 26 \cdot \mathrm{Q} 55 \cdot \mathrm{M} 13$

\section{Green entrepreneurship: an emerging field of research}

The low carbon environmental goods and services (LCEGS) sector has continued to expanded at nearly $4 \%$ per annum while the global turnover in the sector exceeded \$5.4 trillion in 2012 (BIS 2013). Investments into environmentally sustainable technologies ${ }^{1}$ are essential to addressing environmental issues and facilitating the transition into a low carbon economy (Dean and McMullen 2007; Esty and Winston, 2009). They can restore the competitiveness of advanced economies by providing competitive advantages and creating new jobs (Costantini and Mazzanti 2012; Ghisetti and Quatraro 2013).

Extant literature has focussed on how and why existing companies have become more sustainable and environmentally responsible in the emerging green economy, and has paid considerable attention to the identification of barriers and antecedents associated with

\footnotetext{
$\overline{1}$ Following the tradition in this scholarship, the terms "eco", "environmental", "green" and "sustainable" are used interchangeably here to refer to the business activities that achieve a reduced negative impact on the environment (often through traditional pollution cleanup, energy and resource efficiency, reduced carbon emission and environmental degradation, as well as more complex low-carbon and environmental solutions).
} 
established firms "going green". The conventional wisdom of green ventures, as derived from the study of large companies, tends to emphasise the benefits of going green in terms of cost-efficiency, innovation offsets, attendant revenue growth through product differentiation, increased transparency, reduced organisational inertia, better risk management and improved relationships with external stakeholders, and the like (Ambec and Lanoie 2008; Porter and van der Linde 1995). Nevertheless, such logics often fail to apply or apply with significant qualification to their small entrepreneurial counterparts.

Notwithstanding the conceptual appeal of the "green wave" of creative destruction and the predictions that green markets are on track to reach a "critical mass", the scholarly literature exploring entrepreneurial firms that are "born green" has emerged only more recently at the intersection between innovation and entrepreneurship literatures (see, Hall et al. 2010, for a review). Born green firms, used interchangeably with "green startups" here, follow an entrepreneurial path that fulfils the need for a greener and more environmentally friendly approach to business, providing practical and innovative solutions for social and environmental concerns (Criscuolo and Menon 2015; Esty and Winston 2009).

Although still in infancy, the scholarship on green entrepreneurship is gaining increasing visibility in the face of social awareness of corporate responsibility toward environment, and the growing importance of ecological sustainability in strategic business development. Green entrepreneurs exploit the opportunities that are inherent in environmentally relevant market failures (Dean and McMullen 2007); however, the paradox of green entrepreneurship may also emanate from the fact that environmental wellbeing that results from born greens is a public good and, therefore, non-excludable. This property of non-excludability may push green entrepreneurs (along with their nascent breakthrough innovations) into liminal spaces, where additional costs render green entrepreneurs at a competitive disadvantage and, thus, limit their economic impact vis-à-vis non-green actors (Pacheco et al., 2010).

The main motivation of this special issue is to advance the knowledge on green entrepreneurship, as it remains a contentious discourse situated at the crossroads of the green economy and the mainstream economy. While it is broadly perceived that higher levels of human capital reflected by, for instance, education, social class and household values may play a catalytic role in green entrepreneurship, evidence still remains inconclusive as to whether green ventures are founded on a different set of core values such as making the world a better place or if their objectives are primarily rooted in profit maximisation. Also notably, there is little clarity on how born green ventures and their activities evolve as they move through the corporate and technology life cycles. Several recent studies have shed light on the complex reality of entrepreneurs constantly negotiating multilevel tensions between being green and being entrepreneurial through a process of balancing competing pressures in economic activities, social contexts, and ecological philosophies (Hall et al. 2010; O’Neil and Ucbasaran 2016; O’Neill and Gibbs 2016). Yet, more data-based evidence is necessary to better understand the behaviour and performance of green entrepreneurs.

This special issue attempts to integrate the economics and entrepreneurship literatures on new green ventures to advance the scholarship on the role of born green firms. To this end, the 11 articles in this special issue draw on an array of theoretical perspectives from industrial organisation, innovation management, economic geography, and institutional theory. The papers deploy a range of methods such as case studies, interviews, survey methods, and quantitative analyses to provide novel insights and stimulate further debate while paving way for new conceptual developments. Notably, the special issue is organised around four main themes where the published papers place their contribution: (i) industry and corporate life cycle, (ii) role of institutional structure and government, (iii) access to finance, and (iv) geographical clusters and regional drivers of green start-ups. The remainder of this paper is organised as follows. In Section 2, the current underlying knowledge and gaps within the "green entrepreneurship" field are outlined. Section 3 presents an overview of the articles in this special issue and discusses their key contributions. The last section presents the conclusions along with a discussion on potential future lines of scholarly inquiry on green entrepreneurship.

\section{Key insights from the literature and areas for development}

This section reflects on several major streams of research on green entrepreneurship to highlight the knowledge gaps within this discourse. 


\subsection{The green industry and corporate life cycle}

The interconnection among firm age and innovation performance is a topic of lasting interest in the industrial economics and management literatures (Huergo and Jaumandreu 2004; Coad et al. 2016 among others). However, these insights have yet to infiltrate the green entrepreneurship literature where the environmentally friendly product and process innovations dominate the debate (Barbieri et al. 2016). In most markets, born green companies co-exist and compete against their larger and more established counterparts that eventually "go green", warranting a closer examination of the role firm age has on the behaviour and performance of firms in the green domain (Dean and McMullen 2007; Pinkse and Groot 2015).

Firms' ability to introduce and benefit from ecoinnovations depends on where they are in their life cycle as well as on the stage of their industry life cycle (Barbieri et al. 2016; Carrillo-Hermosilla et al. 2010). Yet, little empirical evidence exists to unravel the role of age and industry life cycle for the evolution of green start-ups' innovation and financial performance across different green sectors. Notably, there is little evidence on how the life cycle of environmentally friendly innovations compares to that of standard technologies (Hockerts and Wustenhagen 2010). These issues bear relevant policy and managerial implications in terms of designing appropriate policies (e.g., green R\&D subsidies; the enforcement of environmental regulations) and informing decisions by managers and entrepreneurs operating in the green realm (e.g., decisions on key investments; the optimal combination of green and non-green technologies).

Innovation studies present well-established findings that put the firm and industry life cycle at the heart of understanding the quality and progression of innovations. These studies suggest that, at the beginning of a technology life cycle, young companies are more widespread given the existence of a competitive market structure where product innovation is central to the struggle for setting an industry standard (Abernathy and Clark 1985; Audretsch et al. 2014). However, at the end of a technology life cycle, mature large companies are more common as they are able to take advantage of economies of scale via process innovation due to the existence of a dominant design (Tushman and Anderson 1986; Henderson and Clark 1990). Hence, the potential for existence and growth of green entrepreneurs is likely to be influenced by the stage of the technology life cycle at the point of market entry (Verreynne and Meyer 2010). Moreover, firm's age can act as a moderator of the innovation performance and this moderation usually spans a number of age-specific factors, which help to understand how the innovation process is carried out at different points of a firm's life cycle. For example, new companies usually face high costs of experimentation and they must provide training to new R\&D employees. Older companies, in contrast, are more efficient at introducing process innovations as they have the financial backing entailed by uncertain mid-term returns characterising innovation, and they tend to prefer exploitation over exploration (Coad et al. 2016). As such, young born green companies entering markets with their innovative products and services are likely to face significantly different innovation challenges compared to the more established firms that adopt environmentally friendly innovations as a reaction to the changing industry landscape.

Additionally, born green firms have characteristics that are significantly different from their large and established counterparts. Many of the born green firms emerge as small and medium enterprises (SMEs) from individual entrepreneurs and occasionally from academic or other spin-offs. Unlike their more established and larger counterparts, these new organisations take time to understand sustainability and feasibility before rapidly developing into lucrative and technologically challenging niche green areas. Start-ups within green initiatives are therefore better poised to benefit from radical innovations building on breakthrough eco-technologies, and, at the same time, to internalise negative externalities, regulatory challenges and compliance costs by factoring these into economic decisions upfront and, thus, achieving faster growth and enhanced competitiveness (Ács and Audretsch 1990; Coad et al. 2016; Porter and van der Linde 1995). Yet, most of the literature is still limited to the remits of more established firms, leaving gaps in the understanding of green entrepreneurial firms and their activities. Thus, a full picture of the nuances of greening along the industry life cycle is missing in the literature.

\subsection{The role of institutional structure and government}

According to the institutional theory and its more recently developed derivative, the legitimacy theory, entrepreneurs' perception of institutions and structures can 
exert a profound impact on their activities. Entrepreneurs learn to recognise and act based on institutional and social norms in order to gain legitimacy and for their firm's growth and survival (Bruton et al. 2010; DiMaggio and Powell 1983). Green organisational identity, driven by the preconception of emerging opportunities, needs to meet the expectations of a diverse array of audiences in addition to entrepreneurs' own values and beliefs, as part of the legitimation process of new ventures (O'Neil and Ucbasaran 2016). Companies' pro-environmental behaviour can, therefore, be a quest for legitimacy. This is particularly salient for new green ventures as they have to signal their value to stakeholders such as investors (Harvey and Schaefer 2001; Schaltegger and Hörisch 2015). Institutional structure, thus, constitutes a vital scaffold for elucidating what drives green entrepreneurship (Meek et al. 2010; O'Neil and Ucbasaran 2016).

As an important formal institution, government support plays a critical role in environmental entrepreneurship through the creation of regulatory pressures (Berrone et al. 2013). Governments can make or break companies through legislation and awarded contracts (e.g., the power sector). A higher level of government support for green entrepreneurship often corresponds to a stronger environmental orientation of entrepreneurs (see Hörisch et al. 2017) as well as greater incentives for established companies to become greener over time. Furthermore, rule of law and enforcement of environmental legislation increase the penalty for not being green.

A greater understanding of the institutional environment, with particular emphasis on powerful regulatory institutions is an area where more research is needed. This can shed light on the necessary conditions for the emergence of green entrepreneurship on a larger scale. Furthermore, this can provide new insights into the role of institutions for the performance and survival of green entrepreneurs.

\subsection{Access to finance for green entrepreneurs}

As with many other start-ups, green start-up ventures are often innovatively pursuing inherent technological and managerial risks. They are typically financially constrained with limited or no collateral to offer to their funders (Ning et al. 2015). Extant research suggests that access to finance for start-ups can be significantly hampered by information asymmetries that are abundantly present in the capital markets; such market failures can stem from a plethora of intertwined factors such as uncertainty and complexity of underlying technologies, ambiguity in the assessment criteria by creditors for lack of proven evaluation frameworks, and instability in market demand and regulatory environment (Demirel and Parris 2015; Lerner and Hall 2010; Petkova et al. 2014).

The case of green start-ups can present a grimmer picture compared to the overall population of start-ups for a number of reasons. An earlier study of Randjelovic et al. (2003) identifies the supply side gaps in the provision of private innovation finance to the green sector as resulting from a combination of smaller and weaker group of green business networks and a lack of expertise in the area of green and sustainable businesses. While green entrepreneurs have made great progress in penetrating the mainstream business environment in recent times, they account for a relatively small portion of entrepreneurs while green venture capital is not widely available. As green entrepreneurs continue to suffer from perceptions of higher political and technological risk, their lower scalability and long pay-back periods making them less attractive ventures for finance providers (Migendt et al. 2017).

Bootstrapping and/or the use of public funding sources are classical features of born green ventures at inception although these may be more region-specific. Given the inherent difficulty in distinguishing start-ups that offer environmental products and services in the green sector from those based on green technologies in more traditional industries, the contours associated with green entrepreneurs remain fuzzy. As such, and coupled with the aforementioned information asymmetries, this may partly translate into the inability of external financiers to separate different types of ventures in the startup stage and necessitate particular "green" signals such as green patents or products to indicate the quality of the venture's offerings. In this sense, the emerging body of green finance literature emphasises the relevance of the type of finance that is utilised to fund the activities of green entrepreneurs (Bergset 2015; Migendt 2017). This literature focuses on the differences in the availability of bank, conventional (including philanthropic) venture capital and public funding as sources of finance; and the differentials in the objectives and timelines for expected financial returns by these funding sources. Taking a broad look at the finance ecosystem around UK's green entrepreneurs, Demirel and Parris (2015) note that 
bank loans, the most commonly available form of finance, discriminate against green ventures while venture capital firms and government funds align to serve a rather narrow section of the green economy. Thus, the early stage and basic innovations by green entrepreneurs fail to access finance on most occasions because of the weak green signals they send out to the stakeholders.

Despite a much improved understanding of issues around access to external finance by green innovators (Criscuolo and Menon 2015; Meyskens and Carsrud 2013), there is still a dearth of knowledge around the overlap and timing of distinct financing modes along the business life cycle, where distinct logics apply at different phases, and little is known about the existence and efficacy of the "green" signals from these new ventures for attracting external funding. Furthermore, it is important to consider the close relationship between investor preferences for green start-ups and the policy implications. Bürer and Wüstengahen (2009), Criscuolo and Menon (2015), Mazzucato and Semienuk (2017), among others, show that the regulatory institutions that shape the financial environment largely determine overall investor appetite and behaviour in the context of funding green entrepreneurs. Hence, it is important not to isolate the debate on green finance from the environmental policy and institutional structure literatures.

\subsection{Geographical clusters and regional drivers of green entrepreneurship}

Regions can serve to breed economic competitiveness and growth, and it is well documented that higher startup rates coupled with efficient innovation systems hold the key to success in regional development (Fritsch and Mueller 2004; Audretsch 2007, Harris 2011; Huggins and Thompson 2015). While a large body of literature examines the geographical dimension of entrepreneurship by considering the role of knowledge spillovers for entrepreneurship (Audretsch and Lehman 2005; Acs et al. 2009 among others), the spatial determinants of entrepreneurship (Armington and Acs 2002; Tamvada 2015), factors shaping firm clustering (Henderson et al. 2001; Fujita and Thisse 2013), and the impact of entrepreneurship on the region (Audretsch 2007, Erken et al. 2016, Massón-Guerra and Ortín-Ángel 2017), little is known about the link between green entrepreneurship and the region.

Regional clusters can be substantially facilitated by the rapid adoption of green innovations that improve environmental conditions and sustainability of existing products or processes. Increasing attention has been devoted to the relationship between environmental innovation, business activity and regional policy (Carraro and Siniscaico 1994; Jaffe et al. 2002). However, beyond the policy instrument, the location choice (and therefore formation of clusters) for born green ventures is characterised by substantial complexity contingent on a plethora of factors such as local knowledge stock and spillovers, industry architecture, technological and geographical proximity etc. (Breschi et al. 2003; Boschma and Frenken 2006). External knowledge is complex currency within green entrepreneurship. A growing need for more open modes of innovation in the green sector due to the inherent technological complexities with inter-disciplinarity in its base, emphasises the growing importance of external knowledge and the need for green ventures, industries, governments, universities, and non-governmental organisations (NGOs) to collaborate in order to address common environmental issues and develop necessary technologies to deal with environmental issues.

To date, the combined role of regional clusters, general population awareness, innovation climate, resources, government policies, and institutions in fostering green entrepreneurship is not clear. Furthermore, there is little insight into how the geographical clustering of born green firms evolves dynamically as they move forward along the life cycle.

\section{Contribution of the articles in this special issue}

The contributions in this special issue are diverse in content, focus, method and discipline as a way of reflecting the great diversity among green entrepreneurs. Table 1 presents the list of papers accepted for the special issue and their specific contributions.

The first group of papers in the special issue investigate the relevance of firm and technology life cycle for green start-ups. Leoncini et al. (2017, this issue) use a sample of more than 5000 manufacturing companies in Italy for the period of 2000-2008 and refine existing results on the relationship between green technology and firm growth. The authors show that the stock of knowledge accumulated relating to environmentally friendly technology is important in explaining firm growth. Still, this relationship is contingent on the firm growth distribution, as superstar and struggling 
Table 1 An overview of papers assembled in this special issue

\begin{tabular}{|c|c|c|c|}
\hline Authors & Methodology & Data source & Focus \\
\hline Ball, C.; Kittler, M. & $\begin{array}{l}\text { Qualitative } \\
\text { analysis and } \\
\text { country-based } \\
\text { case study }\end{array}$ & $\begin{array}{l}\text { In-depth interviews and field notes from } \\
\text { industry conferences }\end{array}$ & $\begin{array}{l}\text { Examining environmental entrepreneurs' } \\
\text { perceptions of the importance and } \\
\text { effectiveness of support mechanisms in } \\
\text { removing environmental market failure in } \\
\text { the energy sectors of UK, France, and } \\
\text { Germany. }\end{array}$ \\
\hline $\begin{array}{l}\text { Christensen, J.L.; Hain, } \\
\text { D. S; Nogueira, L.A. }\end{array}$ & $\begin{array}{l}\text { Mixed methods, } \\
\text { econometric } \\
\text { analysis, and } \\
\text { case study }\end{array}$ & Danish Community Innovation Survey (CIS) & $\begin{array}{l}\text { Exploring collaboration activities of } \\
\text { innovators renewable energy with } \\
\text { comparison to non-renewable energy } \\
\text { innovators. }\end{array}$ \\
\hline $\begin{array}{l}\text { Colombelli, A.; } \\
\text { Quatraro, F. }\end{array}$ & $\begin{array}{l}\text { Quantitative and } \\
\text { econometric } \\
\text { analysis }\end{array}$ & $\begin{array}{l}\text { Italian official database of innovative start- } \\
\text { ups }\end{array}$ & $\begin{array}{l}\text { Testing the relevance of local knowledge } \\
\text { stocks, distinguishing between clean and } \\
\text { dirty stocks in the creation of green start- } \\
\text { ups. }\end{array}$ \\
\hline Corradini, C. & $\begin{array}{l}\text { Quantitative and } \\
\text { econometric } \\
\text { regressions }\end{array}$ & ESPON-Eurostat and PATSTAT-Crios & $\begin{array}{l}\text { Examining the spatial determinants of green } \\
\text { technological entry across UK. }\end{array}$ \\
\hline $\begin{array}{l}\text { Giudici, G.; Guerini, } \\
\text { M.; Lamastra, C. R. }\end{array}$ & $\begin{array}{l}\text { Quantitative and } \\
\text { econometric } \\
\text { analysis }\end{array}$ & $\begin{array}{l}\text { Italian official database of innovative start- } \\
\text { ups }\end{array}$ & $\begin{array}{l}\text { Examining the local factors (i.e., the } \\
\text { availability of scientific and technological } \\
\text { knowledge and the environmental } \\
\text { awareness of local governments and } \\
\text { communities) that affect the creation of } \\
\text { cleantech start-ups in a geographical area. }\end{array}$ \\
\hline $\begin{array}{l}\text { Grinevich, G; Huber, } \\
\text { F.; Karatas-Ozkan, } \\
\text { M.; Yavuz, C. }\end{array}$ & $\begin{array}{l}\text { Qualitative } \\
\text { analysis }\end{array}$ & $\begin{array}{l}30 \text { in-depth semi-structured interviews with } \\
\text { founders and executives of UK sharing } \\
\text { platforms }\end{array}$ & $\begin{array}{l}\text { Investigating how entrepreneurial teams in the } \\
\text { sharing economy deal with the complexity } \\
\text { of "greenness" and navigate the } \\
\text { expectations from multiple stakeholders of } \\
\text { various constituents and institutions. }\end{array}$ \\
\hline $\begin{array}{l}\text { Hall, J.; Matos, S.; } \\
\text { Bachor, V. }\end{array}$ & $\begin{array}{l}\text { Qualitative- and } \\
\text { company- } \\
\text { based case- } \\
\text { study analysis }\end{array}$ & In-depth stakeholder interviews & $\begin{array}{l}\text { Examining how green entrepreneurs influence } \\
\text { government regulatory practices in their } \\
\text { attempts to diffuse eco-technology. }\end{array}$ \\
\hline $\begin{array}{l}\text { Leoncini, R.; } \\
\text { Marzucchi, A.; } \\
\text { Montresor, S.; } \\
\text { Rentocchini, F.; } \\
\text { Rizzo, U. }\end{array}$ & $\begin{array}{l}\text { Quantitative and } \\
\text { econometric } \\
\text { analysis }\end{array}$ & $\begin{array}{l}\text { ASIA database of the Italian National } \\
\text { Statistical Office (ISTAT), AIDA, and } \\
\text { PATSTAT }\end{array}$ & $\begin{array}{l}\text { Investigates the relationships between green/ } \\
\text { non-green technologies and firm growth } \\
\text { with particular focus on the corporate life } \\
\text { cycle. }\end{array}$ \\
\hline $\begin{array}{l}\text { Mrkajic, B.; Murtinu, } \\
\text { S.; Scalera, V. G. }\end{array}$ & $\begin{array}{l}\text { Quantitative and } \\
\text { econometric } \\
\text { analysis }\end{array}$ & $\begin{array}{l}\text { RITA (Research on Entrepreneurship in } \\
\text { Advanced Technologies) combined with } \\
\text { (i) the Union of Italian Chambers of } \\
\text { Commerce (Telemaco database) and (ii) the } \\
\text { commercial databases CERVED and } \\
\text { AIDA }\end{array}$ & $\begin{array}{l}\text { Testing whether being born-to-be-green } \\
\text { represents a signal toward potential venture } \\
\text { capital (VC) investors. }\end{array}$ \\
\hline $\begin{array}{l}\text { Shristava, M.; } \\
\text { Tamvada, J. P. }\end{array}$ & $\begin{array}{l}\text { Quantitative and } \\
\text { econometric } \\
\text { analysis }\end{array}$ & Eurobarometer Survey & $\begin{array}{l}\text { Contextualising greening through the lens of } \\
\text { tangibility and visibility of greening } \\
\text { activities and examining the impact of } \\
\text { different types of greening on firm } \\
\text { performance along the age and size } \\
\text { distribution of firms. }\end{array}$ \\
\hline Sunny, S..; Shu, C. & $\begin{array}{l}\text { Quantitative and } \\
\text { econometric } \\
\text { analysis }\end{array}$ & Cleantech i3 database & $\begin{array}{l}\text { Examining how clusters of knowledge } \\
\text { networks, resources, and institutions affect } \\
\text { the creation of clusters of U.S. clean } \\
\text { technology firms. }\end{array}$ \\
\hline
\end{tabular}


companies do not present this effect. The authors also emphasise that the age of the company moderates the positive role of green technology on firm growth in quite an unexpected direction: only relatively mature (over 20 years) firms seem to take on the green growth path. All in all, this contribution sheds doubt on the entrepreneurial propositions of young fast-growth green technology firms and highlights how green growth may depart from the traditional trajectories of technologybased growth.

In a similar vein, Shrivastava and Tamvada (2017, this issue) develop a novel theoretical framework based on the tangibility and visibility of greening strategies to examine the growth dynamics of green start-ups over the course of the firm's life cycle and bring the issue of firm life cycle into the core of the discussion. Their study examines the impact of different greening strategies over the age distribution of firms for more than 9000 European companies. Their results suggest that younger and older firms benefit from different greening strategies. Notably, while younger firms tend to benefit from external greening strategies (e.g. green products and EMS) that signal to the markets and customers their green intentions, firms have to adapt over the course of the firm's life cycle and undertake internal greening strategies (e.g., investing into green production and going beyond compulsory compliance) in order to continue on a green growth path.

The third contribution in this stream by Christensen et al. (2017, this issue) further explores how collaboration patterns of green innovators tend to change as firms age. The paper adopts a mixed-methods approach to investigate the inter-firm collaboration patterns of renewable energy innovators by using the 2014 Community Innovation Survey and a small-scale qualitative study. The findings suggest that renewable energy innovators are more likely to collaborate, and with a more diverse set of partners than non-renewable energy innovators. The authors propose that because the needs of renewable energy innovators vary during their corporate life cycle, the purpose and types of collaborations change accordingly over time. Notably, and in line with the results from the two studies outlined above, they show how entrepreneurial activities are particularly relevant in mature companies in the renewable energy industry: these firms collaborate and integrate their solutions in a complex web of relationships aimed at exploiting the commercialisation of the invention (e.g., access to new clients, development of a supply chain).
The second theme of the special issue focuses on the link between institutions and green entrepreneurship. Hall et al. (2017, this issue) examine the process of commercialization of eco-technologies to convert them into eco-innovations. Using the lens of institutional theory, the authors suggest that entrepreneurs have to pro-actively shape the institutional environment to take their green tech ventures forward, and in the process treat this as a core entrepreneurial strategy. Their results suggest that when agents drive this institutional change, unintended consequences such as erection of new trade barriers may arise that work against the interests of the entrepreneurs.

Ball and Kittler (2017, this issue) examine the role of policy support mechanisms for green energy entrepreneurship in the UK, German, and French energy markets. They suggest that while the entrepreneurs find policy support helpful and encouraging at early stages of the firm's life cycle, the scaling of the green energy activities faces significant challenges, as the markets for large-scale production are better suited to incumbents. This suggests concerns around "green prisons" where policy induced green entrepreneurship fails to scale and grow.

Finally, Grinevich et al. (2017, this issue) combine the nascent literature on green entrepreneurship with two topics that are increasingly gaining attention in the literature: sharing economy and institutional logics. Their paper examines how teams of founders on sharing platforms are able to integrate the logic of environmental sustainability to social and economic logics that characterise an emerging sharing economy. The authors show that teams of founders integrate green with other logics through complexity reducing and complexity absorbing strategies as well as temporal adjustments of logics. Put together these three papers suggest a twoway interaction between institutions and entrepreneurs with green entrepreneurs influencing institutions and getting impacted by them.

The third emergent theme of the special issue focuses on the availability of external finance for green start-ups. Building on the growing literature on access to external finance for entrepreneurial ventures; Mrkajic et al. (2017, this issue) and Shrivastava and Tamvada (2017, this issue) provide insights on the external financing environment for green start-ups. While the former contribution reveals the significance of barriers green startups face in their efforts to gain access to external finance, the latter identifies external finance as a rarely 
available, yet key factor for the growth of green of startups. Mrkajic et al. (2017, this issue) show that born greens that perform green activities and use green technologies are, on average, not more likely to receive $\mathrm{VC}$ funding compared to other high-tech ventures unless the entrepreneur can effectively position her/his venture within such business in the green realm. Emphasising the key role of effective signalling, this paper sheds light on the extent and reasons for barriers to VC finance experienced in the green sector.

The last dominant theme in the special issue is the role of geographical factors that affect and shape the emergence of green clusters. The knowledge spillover theory of entrepreneurship suggests that entrepreneurs exploit opportunities that arise from new knowledge and ideas that have yet to be commercialised (Acs et al. 2009). By exploiting such opportunities arising endogenously from investments in knowledge, entrepreneurs act as a conduit for knowledge spillovers (Audretsch 1995). Colombelli and Quatraro (2017, this issue) combine the knowledge spillovers theory of entrepreneurship with the literature on sustainable entrepreneurship and analyse how the properties of the regional knowledge stock relate to the creation of green start-ups at the regional level. Their results suggest that green knowledge stock exerts a positive effect above and beyond that of non-green knowledge stock. Furthermore, they find that variety in the knowledge base of the region is important for the emergence of green start-ups but this variety should be from related and complementary technologies.

Corradini (2017, this issue) examines the location determinants of new green tech firms across European regions. He finds that green tech entry is skewed across space with only $5 \%$ of NUTS3 regions experiencing green tech entry. In particular, regions that have more technological activities are also the regions that have higher green entrepreneurship levels suggesting that knowledge spillovers and entrepreneurial capabilities within regions play an important role in facilitating green entrepreneurship. Furthermore, the paper suggests that there is an inverted U-shaped relationship between regional relatedness in technology and entry of green firms with technological relatedness increasing the likelihood of green entry until a point and then, having a diminishing effect with further increases in technological relatedness leading to narrowed focus on particular technologies in regions.

Further extending the research on spatial determinants of green entrepreneurship, Giudici et al. (2017, this issue) examine the local determinants of the creation of green tech start-ups in Italy. The authors examine the factors influencing green tech start-ups under two broad categories: (a) the availability of scientific and local knowledge and (b) environmental awareness of local governments and communities. Using a large-scale database, the authors find significant impact of both categories on green firm formation. Their results suggest that high-quality scientific knowledge from local technical universities, local stock of patents, environmentally friendly policies of local governments, and environmental awareness of local communities have a positive impact on clean tech entry in a region. Thus, consistent with Colombelli and Quatraro (2017, this issue) and Corradini (2017, this issue), this paper lends support to the knowledge spillover theory of entrepreneurship. In addition to this, it extends the literature on the spatial determinants of new firm formation (Armington and Acs 2002; Tamvada 2015) by specifically examining the role of environmental policies of local governments and environmental awareness of local communities for cleantech start-ups, suggesting that start-up activities can be influenced by sector-specific local policies and awareness initiatives.

The fourth contribution on the role of region by Sunny and Shu (2017, this issue) examines the impact of clusters on entry by green tech firms across different regions of the USA. This paper suggests that incentive policies have an impact on new firm formation while regional social norms have an impact on clean technology firm formation. The results suggest that there is a significantly positive relationship between the availability of capital and regional clean technology firm formation with geographic proximity reinforcing that relationship, and incentive policies positively moderating the link between capital availability and clean technology firm formation. Put together, these four papers present some of the first insights into the role of knowledge spillovers, regional entrepreneurial capabilities, awareness, and social norms as well as policies that have an impact on green entrepreneurship and significantly extend the current research linking green entrepreneurship and regional location.

\section{Concluding remarks and potential areas for future research}

The literature on green entrepreneurship is in early stages of development with unresolved issues impeding 
the advancement of scholarship on how born green firms behave and perform. The main challenges identified in this special issue provide insights into promising future opportunities for research in four key areas. First, there is a need for a shared definition of green entrepreneurship and consistency in measuring its attributes. Relatedly, the second area for future research concerns the relevant methodological issues that can provide a grounded understanding of green entrepreneurship. A third future challenge refers to the integration of green entrepreneurship into related research fields such as entrepreneurship, innovation studies, and finance in order to explore unanswered research questions at the intersections of these fields. Finally, the creation of more comprehensive databases that capture a broad range of green entrepreneurs across different countries (from both developed and developing background) is essential for researchers to conduct rigorous empirical studies on green entrepreneurship. In the following, we delve deeper in each of the points outlined above.

To ensure more consistent advancement of knowledge in this field, a consensus is needed on what constitutes green entrepreneurship. As outlined in Shapira et al. (2014), the definitions of green sectors, green economy, and green jobs remain vague, creating an obstacle for progress in this research field. While a degree of diversity is certainly expected and beneficial here, clarity on key elements of green entrepreneurship, while allowing for diversity within this definition through subcategories of green entrepreneurship, is essential to ensure that future research develops along a strong and coherent trajectory. Similarly, a better understanding of what constitutes green goods, services, processes, and jobs is essential along with an examination of how traditional industry classifications fare according to green activities and green jobs. The environmental sustainability characteristics of born green companies can refer to a wide range of factors that are as distinct as environmental management performance (Darnall and Edwards 2006), green technologies (Meyskens and Carsrud 2013), individual commitment toward the environment by a team of founders (Kuckertz and Wagner 2010), creation of environmentally sustainable skills in the workforce (Marin et al. 2015; Consoli et al. 2016), and so on. A better understanding of how all of these aspects relate to each other and contribute to the creation and development of born green firms can greatly advance this research area. For example, future research can focus on how green initiatives and practices by founders provide genetic environmental foundations that in turn inform the development of green technologies and firm outcomes.

Such efforts are likely to benefit the second limitation in terms of data access and analysis. While some large databases present opportunities for identification of green start-ups among the population of entrepreneurial ventures, most of commonly used data sources shed little light on green activities. Collaborating with the coordinators of databases to integrate simple and coherent indicators of green activity can open up important research opportunities. This is the case with some regional variants of Community Innovation Survey in Europe that have started incorporating questions related to greening activities of firms. Individually coordinated databases by researchers in different geographies present interesting, yet small, samples of green entrepreneurs and these efforts feed our understanding and knowledge of this type of firms. Yet, a more coordinated and consistent approach is often not present in these efforts, limiting comparability across different studies.

Even when extensive data sources are available, such as in the case of eco-innovations which make use of patent data, these sources are far from being comprehensive and fully reliable. The identification of ecoinnovations by means of technological patent classes often rely on official classifications provided by international research organisations (such the OECD and WIPO) which can be rigid, rendering it difficult to identify novel technological breakthroughs and can be subject to Type I errors with a disproportionately large number of "false positives". A more coordinated effort and collection of larger-scale data will benefit the cause of advancing green entrepreneurship research. Notably, the growing use of machine learning methods are likely to complement these efforts and open up new avenues of research (Varian 2014; Székely and Vom Brocke 2017), provided green entrepreneurship and green activities in general can be conceptualised and defined consistently.

A third area where improvement is urgently needed is better embedding and enlarging the reach of green entrepreneurship by following recent trends in existing areas of research. On the theoretical side, the literature has shown significant progress made in both fields of entrepreneurship (Meyskens and Carsrud, 2013) and eco-innovation (Hoogendoorn et al. 2015) for small and young firms. Yet, only a small number of studies bridge these insights to equip green entrepreneurship literature with a sound theoretical framework. One of 
the objectives of this special issue is to lay out some ground work for a strong theoretical framework by bringing together approaches from different disciplines in management and economics. For example, evidence from different papers in this special issue points to the differential ability of young companies to transform green technologies into performance. One reason put forward by these works relates to the complexity of green technology given its early stage. Looking at the innovation barriers as well as failure in innovation activities faced by born green companies can inform both recent attempts in the innovation literature (Marin et al. 2015; D'Este et al. 2014) as well as the conundrum found by the papers in this special issue. Evidently, these studies contained here may have only scratched the surface of the problem and future work should try to dig deeper into this. Such an approach will not only make the field more robust, it will also open up new opportunities for research in fields from these disciplines (e.g., exploration of open innovation opportunities for green start-ups such as in De Marchi 2012; Ghisetti et al. 2015).

Finally, a current weakness in the field of green entrepreneurship is that it frequently relies on evidence from a single country or industry setting, and almost entirely based in advanced economies. Although green entrepreneurship is often perceived to provide a sustained source of new advantages to advanced economies, its role in more impoverished communities should be equally significant (if not more) as environmental issues coupled with social and economic pressures are often at the forefront of developmental objectives (Hall et al. 2010). Cross-country evidence (especially from developing economies) is, therefore, largely needed in the form of context-specific studies that take into account the social-economic conditions in which green entrepreneurship is embedded.

Acknowledgements We are grateful to the editor David Audretsch for supporting this nascent research agenda. Scholars interested in the special issue were invited to present their work at the "Born To Be Green: Economics and Management of Green Start-Ups" workshop organised at University of Southampton in May 2015. We thank ESRC Project (ES/L000628/1-2) Innovating for a Low Carbon Economy, the British Academy of Management (BAM), and the Society for Advancement of Management Studies (SAMS) for sponsoring the workshop, and the workshop participants for stimulating discussions. Following formal submissions to the journal and a double-blind peer review process, a selection of papers were accepted for publication in this special issue. We are thankful to the reviewers who provided valuable comments while assessing the submissions, and the editorial team of Adam Lederer at the Small Business Economics Journal for their excellent support.

Open Access This article is distributed under the terms of the Creative Commons Attribution 4.0 International License (http:// creativecommons.org/licenses/by/4.0/), which permits unrestricted use, distribution, and reproduction in any medium, provided you give appropriate credit to the original author(s) and the source, provide a link to the Creative Commons license, and indicate if changes were made.

\section{References}

Abernathy, W. J., \& Clark, K. B. (1985). Innovation: mapping the winds of creative destruction. Research Policy, 14(1), 3-22.

Ács, Z. J., \& Audretsch, D. B. (1990). Innovation and small firms. MIT Press. https://mitpress.mit.edu/books/innovation-andsmall-firms. Accessed 20 June 2017.

Acs, Z. J., Audretsch, D. B., Braunerhjelm, P., \& Carlsson, B. (2009). The knowledge spillover theory of entrepreneurship. Small Business Economics, 32(1), 15-30.

Ambec, S., \& Lanoie, P. (2008). Does it pay to be green? A systematic overview. Academy of Management Perspectives, 22(4), 45-62. https://doi.org/10.5465 /AMP.2008.35590353.

Armington, C., \& Acs, Z. J. (2002). The determinants of regional variation in new firm formation. Regional Studies, 36(1), 3345 .

Audretsch, D. B. (1995). Innovation and industry evolution. Cambridge: MIT Press.

Audretsch, D. B. (2007). Entrepreneurship capital and economic growth. Oxford Review of Economic Policy, 23(1), 63-78.

Audretsch, D., \& Lehmann, E. (2005). Does the knowledge spillover theory of entrepreneurship hold for regions? Research Policy, 34(8), 1191-1202.

Audretsch, D. B., Segarra, A., \& Teruel, M. (2014). Why don't all young firms invest in R\&D? Small Business Economics, 43(4), 751.

Ball, C. \& Kittler, M. (2017). Removing environmental market failure through support mechanisms: insights from green start-ups in the British, French and German energy sectors. Small Business Economics, forthcoming in this issue.

Barbieri, N., Ghisetti, C., Gilli, M., Marin, G., \& Nicolli, F. (2016). A survey of the literature on environmental innovation based on main path analysis. Journal of Economic Surveys, 30(3), 596-623.

Bergset, L. (2015). The rationality and irrationality of financing green start-ups. Administrative Sciences, 5(4), 260-285.

Berrone, P., Fosfuri, A., Gelabert, L., \& Gomez-Mejia, L. (2013). Necessity as the mother of "green" inventions: institutional pressures and environmental innovations: necessity as the mother of "green" inventions. Strategic Management Journal, 34(8), 891-909. https://doi.org/10.1002/smj.2041.

BIS (2013). Low carbon environmental goods and services (LCEGS) Report for 2011/12. https://biobs.jrc.ec.europa. $\mathrm{eu} / \mathrm{sites} / \mathrm{default} /$ files/generated/files/policy/Wales 
Lowcarbon-and-environmental-goods-and-services- $\% 28$ LCEGS\%29_report-2011.pdf. Accessed 19 June 2017.

Boschma, R. A., \& Frenken, K. (2006). Why is economic geography not an evolutionary science? Towards an evolutionary economic geography. Journal of Economic Geography, 6, 273-302.

Breschi, S., Lissoni, F., \& Malerba, F. (2003). Knowledgerelatedness in firm technological diversification. Research Policy, 32, 69-87.

Bruton, G. D., Ahlstrom, D., \& Li, H. L. (2010). Institutional theory and entrepreneurship: where are we now and where do we need to move in the future? Entrepreneurship: Theory and Practice, 34(3), 421-440. https://doi.org/10.1111 j. 1540-6520.2010.00390.x.

Bürer, M. J., \& Wüstenhagen, R. (2009). Which renewable energy policy is a venture capitalist's best friend? Empirical evidence from a survey of international cleantech investors. Energy Policy, 37(12), 4997-5006.

Carraro, C., \& Siniscaico, D. (1994). Environmental policy reconsidered: the role of technological innovation. European Economic Review, 38(3-4), 545-554. https://doi. org/10.1016/0014-2921(94)90090-6.

Carrillo-Hermosilla, J., del Río, P., \& Könnölä, T. (2010). Diversity of eco-innovations: reflections from selected case studies. Journal of Cleaner Production, 18, 1073-1083.

Christensen, J. L., Hain, D. S., \& Nogueira, L. A. (2017). Joining forces: collaboration patterns and performance of renewable energy innovators. Small Business Economics, forthcoming in this issue.

Coad, A., Segarra, A., \& Teruel, M. (2016). Innovation and firm growth: does firm age play a role? Research Policy, 45(2), 387-400. https://doi.org/10.1016/j.respol.2015.10.015.

Colombelli, A. \& Quatraro, F. (2017). Green startups and local knowledge spillovers from clean and dirty technologies. Small Business Economics, forthcoming in this issue.

Consoli, D., Marin, G., Marzucchi, A., \& Vona, F. (2016). Do green jobs differ from non-green jobs in terms of skills and human capital? Research Policy, 45(5), 1046-1060.

Corradini, C. (2017). Location determinants of green technological entry: evidence from European regions. Small Business Economics, forthcoming in this issue.

Costantini, V., \& Mazzanti, M. (2012). On the green and innovative side of trade competitiveness? The impact of environmental policies and innovation on EU exports. Research Policy, 41(1), 132-153. https://doi.org/10.1016/j. respol.2011.08.004.

Criscuolo, C., \& Menon, C. (2015). Environmental policies and risk finance in the green sector: cross-country evidence. Energy Policy, 83, 38-56. https://doi.org/10.1016/j. enpol.2015.03.023.

Darnall, N., \& Edwards, D. (2006). Predicting the cost of environmental management system adoption: the role of capabilities, resources and ownership structure. Strategic Management Journal, 27(4), 301-320. https://doi. org/10.1002/smj.518.

De Marchi, V. (2012). Environmental innovation and R\&D cooperation: empirical evidence from Spanish manufacturing firms. Research Policy, 41, 614-623.

Dean, T. J., \& McMullen, J. S. (2007). Toward a theory of sustainable entrepreneurship: reducing environmental degradation through entrepreneurial action. Journal of Business
Venturing, 22(1), 50-76. https://doi.org/10.1016/j. jbusvent.2005.09.003.

Demirel, P., \& Parris, S. (2015). Access to finance for innovators in the UK's environmental sector. Technology Analysis \& Strategic Management, 27(7), 782-808. https://doi. org/10.1080/09537325.2015.1019849.

D’Este, P., Rentocchini, F., \& Vega-Jurado, J. (2014). The role of human capital in lowering the barriers to engaging in innovation: evidence from the Spanish innovation survey. Industry and Innovation, 2l(1), 1-19.

DiMaggio, P. J., \& Powell, W. W. (1983). The iron cage revisited: institutional isomorphism and collective rationality in organizational fields. American Sociological Review, 48(2), 147. https://doi.org/10.2307/2095101.

Erken, H., Donselaar, P., \& Thurik, R. (2016). Total factor productivity and the role of entrepreneurship. The Journal of Technology Transfer, 1-29.

Esty, D. C., \& Winston, A. S. (2009). Green to gold: how smart companies use environmental strategy to innovate, create value, and build competitive advantage. John Wiley \& Sons.

Fritsch, M., \& Mueller, P. (2004). Effects of new business formation on regional development over time. Regional Studies, 38(8), 961-975. https://doi.org/10.1080/0034340042000280965.

Fujita, M., \& Thisse, J. F. (2013). Economics of agglomeration: cities, industrial location, and globalization. Cambridge University Press.

Ghisetti, C., \& Quatraro, F. (2013). Beyond inducement in climate change: does environmental performance spur environmental technologies? A regional analysis of cross-sectoral differences. Ecological Economics, 96, 99-113. https://doi. org/10.1016/j.ecolecon.2013.10.004.

Ghisetti, C., Marzucchi, A., \& Montresor, S. (2015). The open eco-innovation mode. An empirical investigation of eleven European countries. Research Policy, 44(5), 1080-1093.

Giudici, G., Guerini, M. \& Lamastra, C. R. (2017). The creation of cleantech startups at the local level: the role of knowledge availability and environmental awareness. Small Business Economics, forthcoming in this issue.

Grinevich, V., Huber, F., Karatas-Ozkan, M. \& Yavuz, C. (2017). Green entreprenurship in the sharing economy: utilising multiplicity of institutional logics. Small Business Economics, forthcoming in this issue.

Hall, J. K., Daneke, G. A., \& Lenox, M. J. (2010). Sustainable development and entrepreneurship: past contributions and future directions. Journal of Business Venturing, 25(5), 439-448. https://doi.org/10.1016/j.jbusvent.2010.01.002.

Hall, J., Matos, S. \& Bachor, V. (2017) From green technology development to green innovation: inducing regulatory adoption of pathogen detection technology for sustainable forestry. Small Business Economics, forthcoming in this issue.

Harris, R. (2011). Models of regional growth: past, present and future. Journal of Economic Surveys, 25(5), 913-951. https://doi.org/10.1111/j.1467-6419.2010.00630.x.

Harvey, B., \& Schaefer, A. (2001). Managing relationships with environmental stakeholders: a study of U.K. water and electricity utilities. Journal of Business Ethics, 30(3), 243-260. https://doi.org/10.1023/A:1006356928957.

Henderson, R. M., \& Clark, K. B. (1990). Architectural innovation: the reconfiguration of existing product technologies and the failure of established firms. Administrative Science Quarterly, 35, 9-30. 
Henderson, J. V., Shalizi, Z., \& Venables, A. J. (2001). Geography and development. Journal of Economic Geography, 1(1), 81-105.

Hockerts, K., \& Wüstenhagen, R. (2010). Greening Goliaths versus emerging Davids - theorizing about the role of incumbents and new entrants in sustainable entrepreneurship. Journal of Business Venturing, 25(5), 481-492.

Hoogendoorn, B., Guerra, D., \& van der Zwan, P. (2015). What drives environmental practices of SMEs? Small Business Economics, 44(4), 759-781.

Hörisch, J., Kollat, J., \& Brieger, S. A. (2017). What influences environmental entrepreneurship? A multilevel analysis of the determinants of entrepreneurs' environmental orientation. Small Business Economics, pp. 47-69. Springer US. https://doi.org/10.1007/s11187-016-9765-2.

Huergo, E., \& Jaumandreu, J. (2004). How does probability of innovation change with firm age? Small Business Economics, 22, 193-207.

Huggins, R., \& Thompson, P. (2015). Entrepreneurship, innovation and regional growth: a network theory. Small Business Economics, 45(1), 103-128. https://doi.org/10.1007/s11187015-9643-3.

Jaffe, A. B., Newell, R. G., \& Stavins, R. N. (2002). Environmental policy and technological change. Environmental and Resource Economics, 22(1/2), 41-70. https://oi.org/10.1023/A:1015519401088.

Kuckertz, A., \& Wagner, M. (2010). The influence of sustainability orientation on entrepreneurial intentions - investigating the role of business experience. Journal of Business Venturing, 25(5), 524-539.

Leoncini, R., Marzucchi, A., Montresor, S., Rentocchini, F., \& Rizzo, U. (2017). Better late than never: the interplay between green technology and age for firm growth. Small Business Economics, forthcoming in this issue. http://www. sustainability-seeds.org/papers/RePec/srt/wpaper/0616.pdf.

Lerner, J., \& Hall, B. H. (2010). The financing of R\&D and innovation. In Bronwyn $\mathrm{H}$ Hall and Nathan Rosenberg. (Ed.), Handbook of the Economics of Innovation (Vol. 1). Elsevie. https://doi.org/10.1287/mnsc.2015.2404.

Marin, G., Marzucchi, A., \& Zoboli, R. (2015). SMEs and barriers to eco-innovation in the EU: exploring different firm profiles. Journal of Evolutionary Economics, 25(3), 671-705.

Massón-Guerra, J. L., \& Ortín-Ángel, P. (2017). Regional entrepreneurship capital and firm production. Small Business Economics, 1-13.

Mazzucato, M. \& Semieniuk, G. (2017). Financing renewable energy: who is financing what and why it matters. forthcoming in Technological Forecasting and Social Change. https://doi.org/10.2139/ssrn.2796552

Meek, W. R., Pacheco, D. F., \& York, J. G. (2010). The impact of social norms on entrepreneurial action: evidence from the environmental entrepreneurship context. Journal of Business Venturing, 25(5), 493-509. https://doi.org/10.1016/j. jbusvent.2009.09.007.

Meyskens, M., \& Carsrud, A. L. (2013). Nascent greentechnology ventures: a study assessing the role of partnership diversity in firm success. Small Business Economics, 40(3), 739-759. https://doi.org/10.1007/s11187-011-9400-1.

Migendt, M., Polzin, F., Schock, F., Täube, F., \& Flotow, P. (2017). Beyond venture capital: an exploratory study of the finance- innovation-policy nexus in cleantech. Industrial and Corporate Change. https://doi.org/10.1093/icc/dtx014.

Mrkajic, B., Murtinu, S. \& Scalera, V. G. (2017). Is green the new gold? Venture capital and green entrepreneurship. Small Business Economics, forthcoming in this issue.

Ning, Y., Wang, W., \& Yu, B. (2015). The driving forces of venture capital investments. Small Business Economics, 44(2), 315-344.

O’Neil, I., \& Ucbasaran, D. (2016). Balancing "what matters to me" with "what matters to them": exploring the legitimation process of environmental entrepreneurs. Journal of Business Venturing, 31(2), 133-152. https://doi.org/10.1016/j. jbusvent.2015.12.001.

O’Neill, K., \& Gibbs, D. (2016). Rethinking green entrepreneurship - fluid narratives of the green economy. Environment and Planning A, 48(9), 1727-1749. https://doi.org/10.1177 $/ 0308518 X 16650453$.

Pacheco, D. F., Dean, T. J., \& Payne, D. S. (2010). Escaping the green prison: entrepreneurship and the creation of opportunities for sustainable development. Journal of Business Venturing, 25(5), 464-480. https://doi.org/10.1016/j. jbusvent.2009.07.006.

Petkova, A. P., Wadhwa, A., Yao, X., \& Jain, S. (2014). Reputation and decision making under ambiguity: a study of U.S. venture capital firms' investments in the emerging clean energy sector. Academy of Management Journal, 57(2), 422-448. https://doi.org/10.5465/amj.2011.0651.

Pinkse, J., \& Groot, K. (2015). Sustainable entrepreneurship and corporate political activity: overcoming market barriers in the clean energy sector. Entrepreneurship Theory and Practice, 39, 633-654.

Porter, M. E., \& van der Linde, C. (1995). Toward a new conception of the environment-competitiveness relationship. Journal of Economic Perspectives, 9(4), 97-118. https://doi.org/10.1257/jep.9.4.97.

Randjelovic, J., O'Rourke, A. R., \& Orsato, R. J. (2003). The emergence of green venture capital. Business strategy and the environment, 12(4), 240-253.

Schaltegger, S., \& Hörisch, J. (2015). In search of the dominant rationale in sustainability management: legitimacy- or profitseeking? Journal of Business Ethics, 1-18.

Shapira, P., Gök, A., Klochikhin, E., \& Sensier, M. (2014). Probing "green" industry enterprises in the UK: a new identification approach. Technological Forecasting and Social Change, 85, 93-104. https://doi.org/10.1016/j. techfore.2013.10.023.

Shrivastava, M. \& Tamvada, J. P. (2017) Which green matters for whom? Greening and firm performance across age and size distribution of firms. Small Business Economics, forthcoming in this issue. http://eprints.soton.ac.uk/id/eprint/411017.

Sunny, S. A. \& Shu, C. (2017). Investments, incentives and innovation: geographical clustering dynamics as drivers of sustainable entrepreneurship. Small Business Economics, forthcoming in this issue.

Székely, N., \& Vom Brocke, J. (2017). What can we learn from corporate sustainability reporting? Deriving propositions for research and practice from over 9,500 corporate sustainability reports published between 1999 and 2015 using topic modelling technique. PloS One, 12(4), e0174807. https://doi.org/10.1371/journal.pone.0174807. 
Tamvada, J. P. (2015). The spatial distribution of self-employment in India: evidence from semiparametric geoadditive models. Regional Studies, 49(2), 300-322.

Tushman, M. L., \& Anderson, P. (1986). Technological discontinuities and organizational environments. Administrative Science Quarterly, 31(3), 439-465.
Varian, H. R. (2014). Big data: new tricks for econometrics. Journal of Economic Perspectives, 28(2), 3-28.

Verreynne, M. L., \& Meyer, D. (2010). Small business strategy and the industry life cycle. Small Business Economics, 35(4), 399-416. 